Jahrbuch für Geschichte Lateinamerikas

Anuario de Historia de América Latina

$57|2020|$ 122-152

\title{
Christoph Rosenmüller
}

Middle Tennessee State University, Murfreesboro

Del "querido amigo" al "partido antigubernativo": la política imperial y la detención de clientes virreinales en la Nueva España, 1746-1768
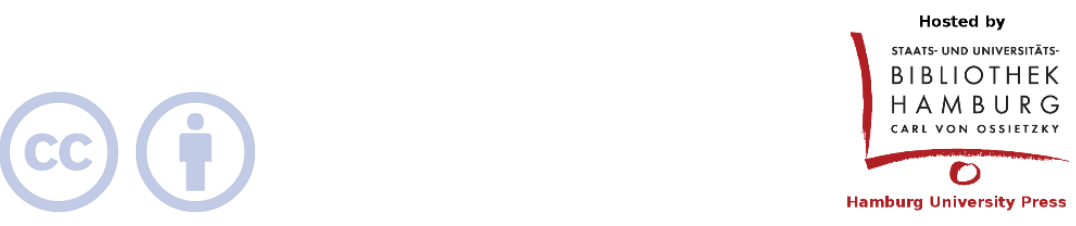

Except where otherwise noted, this article is licensed under a

Creative Commons Attribution 4.0 International license (CC BY 4.0)

https://doi.org/10.15460/jbla.57.190 


\title{
Del "querido amigo" al "partido antigubernativo": la política imperial y la detención de clientes virreinales en la Nueva España, 1746-1768
}

\author{
Christoph Rosenmüller
}

Abstract. - The viceroy first Count of Revillagigedo (1746-1755) seized the administration of the excise tax (alcabalas) of Mexico City from the merchant guild (consulado) with the assistance of Cathedral Canon Ignacio Felipe Cevallos and a group of merchants. Cevallos and other clients also attained important viceregal support or appointments. When Revillagigedo died, however, Viceroy Marquis de Croix and the investigative judge José de Gálvez (1765-1771) accused Cevallos and seven other former viceregal clients of opposing the expulsion of the Jesuits in 1767. Six of them were sent to Spain. This article traces the fate of these clients in the changing local and imperial settings from Revillagigedo's term to Gálvez's Visita General and beyond. While scholars have argued that Croix charged members of an "antigovernmental party", I show that several of them had originally been progovernment because of their ties to Revillagigedo. I also agree with the scholarship that the Visita General did not exclusively target Creoles and Natives, as it also clashed with a network of former viceregal partisans of various regional extractions, including Spain.

Keywords: Viceroys, Visita General, Social Networks, Reforms, Consulado, Antigovernmental Party, José de Gálvez, Revillagigedo, Croix.

Resumen. - En este artículo, reinterpreto el carácter del grupo novohispano que el virrey Carlos Francisco de Croix, marqués de Croix (1766-1771), deportó de Nueva España por oponerse a la expulsión de los jesuitas en 1767. Por lo menos la mitad de los acusados habían entablado una alianza con el virrey primer conde de Revillagigedo (1746-1755), quien utilizó su influencia para colocarlos en plazas importantes. Este grupo incluía al canónigo de la Catedral de México, Ignacio Felipe Cevallos Villagutierre (1710-1784), el más estrecho colaborador del virrey en asuntos hacendísticos. Cevallos también asistió al virrey en tejer lazos sociales con varios mercaderes que le ayudaron en quitar la administración de la alcabala al consulado de comerciantes de México, aunque esos mercaderes no sufrieron castigos durante el conflicto por los 
jesuitas. Mientras que los historiadores han argumentado que Croix acusó a los miembros de un "partido antigubernativo", muestro que varios de ellos habían sido originalmente pro-gobierno al alinearse con las medidas de Revillagigedo. En este sentido también concuerdo con los historiadores que han señalado que la famosa visita general de José de Gálvez (1765-1771) no se enfrentó exclusivamente a criollos y nativos, e intento demostrar que también chocó con una red de antiguos partidarios virreinales de procedencia regional diversa.

Palabras clave: virreyes, visita general, redes sociales, reformas, consulado, partido antigubernativo, José de Gálvez, Revillagigedo, Croix.

\section{Introducción}

El virrey Carlos Francisco marqués de Croix (1766-1771) acusó a dieciséis novohispanos de oponerse a la expulsión de los jesuitas en 1767 y la Corona exilió a once de ellos del territorio novohispano. La acusación caracterizó al conjunto y la impronta del grupo opositor sería retomada por historiadores que estudiaron el destierro. En este artículo, sin embargo, reinterpreto el carácter de este grupo y muestro que por lo menos la mitad de ellos habían entablado anteriormente una alianza con el virrey Juan Francisco de Güemes y Horcasitas, primer conde de Revillagigedo (1746-1755), quien los nombró para ocupar puestos importantes. Este grupo incluía al canónigo de la Catedral de México, el doctor Ignacio Felipe Cevallos Villagutierre (1710-1784), el más estrecho colaborador de Revillagigedo en asuntos hacendísticos. Cevallos también asistió al virrey en tejer lazos sociales con varios mercaderes que le ayudaron en la tarea de quitar la administración de la alcabala al consulado de comerciantes de México, aunque esos mercaderes no sufrieron castigos durante el conflicto por los jesuitas. Rastreo a dichos clientes virreinales dentro del marco del vaivén imperial entre Madrid y México principalmente a partir de 1746 a 1768, aunque también arrojo luz sobre el destino de algunos de ellos después del destierro. Abrevo por gran parte de un importante diario de la época, las relaciones de mérito y la correspondencia privada del virrey conservada en el archivo familiar. ${ }^{1}$

1 José Manuel de Castro Santa-Anna, Diario de sucesos notables. Documentos para la historia de Méjico, México: Imprenta de Juan R. Navarro, 1854, vols. IV-IV; 
El análisis de las redes clientelares en la sociedad novohispana constituye un campo de estudio con grandes avances. Los eruditos se enfocan en los séquitos de los virreyes y han sostenido desde la década de 1970 que los virreyes ejercían un vasto, aunque decreciente poder de patronazgo para nombrar alcaldes mayores y otros oficiales, y que los virreyes sucesores a menudo favorecían a sus propios criados y recibían con frialdad a los de sus predecesores. ${ }^{2}$ No obstante, algunos criados lograron congraciarse con varios virreyes. Más allá de los séquitos, Michel Bertrand demuestra que una red de funcionarios en varias instituciones cooptó al virrey para controlar la Real Hacienda hasta el grado que frustraron la visita de Pedro Domingo de Contreras (1729-1733). ${ }^{3}$ Según este punto de vista, las redes locales se oponían

Archive of the Counts of Revillagigedo, [ACR], Biblioteca de la Universidad de Florida, Gainesville, Department of Special and Area Collections, citado según el rollo de microfilm. Agradezco a Mark A. Burkholder, de la Universidad de Missouri en Saint Louis, y a Javier Sanchiz de la UNAM, por sus sugerencias prosopográficas.

2 Ainara Vázquez Varela, "La corte virreinal de Manuel de Guirior en Nueva Granada (1772-1776)": Francisco A. Eissa-Barroso / Ainara Vázquez Varela / Silvia EspeltBombín (eds.), Élites, representación y redes atlánticas en la Hispanoamérica moderna, Zamora, Michoacán: El Colegio de Michoacán, 2017, pp. 175-214; sobre el marcado declive del patronazgo virreinal a finales del siglo XVII, véase Christoph Rosenmüller, Corruption and Justice in Colonial Mexico. 1650-1755, Cambridge: Cambridge University Press, 2019, pp. 123-152; la historiografía clásica ya analizó el perfil del patronazgo virreinal, véase Alberto Yalí Román, "Sobre alcaldías mayores y corregimientos en Indias. Un ensayo de interpretación": Jahrbuch für Geschichte von Staat, Wirtschaft und Gesellschaft Lateinamerikas, 9 (1972), pp. 28-30; Horst Pietschmann, “Alcaldes Mayores, Corregidores und Subdelegados. Zum Problem der Distriktsbeamtenschaft im Vizekönigreich Neuspanien" Jahrbuch für Geschichte von Staat, Wirtschaft und Gesellschaft Lateinamerikas, 9 (1972), p. 188, véase también Alejandro Cañeque, The King's Living Image. The Culture and Politics of Viceregal Power in Colonial Mexico, New York: Routledge, 2004, pp. 157-175.

3 Michel Bertrand, Grandeur et misères de l'office. Les officiers de finances de Nouvelle-Espagne, XVIIe-XVIIIe siècles, Paris: Publications de la Sorbonne, 1999, p. 267; Michel Bertrand, "Clientélisme et pouvoir en Nouvelle-Espagne": Raquel Thiercelin (ed.), Cultures et sociétes. Andes et Méso-Amérique. Mélanges en l'honneur de P. Duviols, Aix-en-Provence: Publications de l'Université de Provence, 1992, pp. 140-148; véase también Christoph Rosenmüller, Patrons, Partisans, and Palace Intrigues. The Court Society of Colonial Mexico, 1702-1710, Calgary: Calgary University Press, 2008, pp. 76-77. 
principalmente a las iniciativas de la Corona. En este sentido, Luis Navarro García y David Brading argumentaron ya hace años que Croix detectó un 'partido antigubernativo'que intentó frustrar la expulsión de los jesuitas. ${ }^{4}$

Sin embargo, se desconocía que por lo menos una parte de estas personas eran originalmente progubernativo, debido a su relación con Revillagigedo. Éste era un grupo de inclinación projesuita, lo que establece un cierto paralelismo con la coalición política liderada en Madrid por el patrón de Revillagigedo, el marqués de la Ensenada (1743-1754). Historiadores han estudiado con profundidad el desarrollo de la política y las cábalas de la corte española, pero la negociación de cambios entre los virreyes, sus clientes y adversarios en Nueva España son menos conocidos, y las de Revillagigedo se desconocen aún más. ${ }^{5}$

Originalmente, los académicos interpretaron la visita general de la Nueva España por José de Gálvez (1765-1771) como el inicio de un asalto autoritario a la autodeterminación criolla que fortaleció el control real y aumentó los ingresos fiscales. La visita introdujo el estanco del tabaco y del aguardiente, aumentó los pagos del tributo, desprivatizó la recaudación de las alcabalas en varios distritos, vigiló y hasta cierto punto se apoderó de las cajas de comunidad. Por esta razón, Barbara y Stanley Stein minimizaron el primer "medio siglo de proyectos borbónicos de 'reforma' que no habían llegado a ninguna

\footnotetext{
4 Luis Navarro García, "Destrucción de la oposición política en México por Carlos III": Naveg@mérica. Revista electrónica de la Asociación Española de Americanistas, 1: 1 (2008), p. 13, originalmente publicado en separata de Anales de la Universidad Hispalense, 24 (1964), pp. 13-46; David Brading, Miners and Merchants in Bourbon Mexico. 1763-1810, Cambridge: Cambridge University Press, 1971, p. 39; David Brading, Church and State in Bourbon Mexico. The Diocese of Michoacán 1749-1810, Cambridge: Cambridge University Press, 1994, pp. 4-5, 12-16.

5 Un ejemplo es Pablo Fernández Albaladejo, Fragmentos de Monarquía, Madrid: Alianza, 1992, pp. 353-411; Antonio del Valle Menéndez, Juan Francisco de Güemes y Horcasitas. Primer Conde de Revillagigedo. Virrey de México. La historia de un soldado (1681-1766), Santander: Librería Estudios, 1998, es una exhaustiva biografía pero que arroja poca luz sobre el clientelismo virreinal. Respecto a política novohispana, véase también Rosenmüller, Corruption, pp. 222-254.
} 
parte". 6 Felipe Castro, en su estudio sobre grupos populares, concuerda en que Gálvez representó "un nuevo autoritarismo", ya que la "intromisión del Estado en ámbitos que anteriormente la población consideraba como privados" provocó la protesta de mineros, indios, y criollos en 1767..$^{7}$ Mientras algunos eruditos dudan de la eficacia de las reformas a nivel regional, ${ }^{8}$ Horst Pietschmann sostiene que Carlos III no dirigió las políticas exclusivamente en contra de los criollos, sino contra los monopolios y las estructuras oligárquicas de poder y en favor de los individuos que se desempeñaban en un mercado más libre. ${ }^{9}$ Además, los académicos ahora concuerdan que las reformas carolinas y poscarolinas intervinieron en la economía, las finanzas, la iglesia y otras ámbitos de la vida colonial en fases diferentes, durante las cuales cambiaban actores, afectados, objetivos y resultados. ${ }^{10}$ En el caso

${ }^{6}$ Barbara H. Stein / Stanley J. Stein, Apogee of Empire. Spain and New Spain in the Age of Charles III. 1759-1789, Baltimore / Londres: The Johns Hopkins Press, 2003, p. viii; Barbara H. Stein / Stanley J. Stein, Silver, Trade, and War. Spain and America in the Making of Early Modern Europe, Baltimore / Londres: The Johns Hopkins Press, 2000, p. 232, añadieron que "hacia 1740 [...] la peor de las crisis españolas del siglo XVIII parecía haber remitido en un estancamiento somnoliento"; véase también pp. 263-266; véase además a Gabriel B. Paquette, Enlightenment, Governance, and Reform in Spain and Its Empire. 1759-1808, Houndmills, New York: Palgrave Macmillan, 2008, p. 2.

7 Felipe Castro Gutiérrez, Nueva ley y nuevo rey. Reformas borbónicas y rebelión popular en Nueva España, México: UNAM, 1996, pp. 97, 275.

8 Anthony McFarlane, Colombia before Independence. Economy, Society, and Politics under Bourbon Rule, Cambridge: Cambridge University Press, 1993, pp. 24

9 Horst Pietschmann, "Antecedentes políticos de México. 1808. Estado territorial, estado novohispano, crisis política y desorganización constitucional": Pilar Gonzalbo Aizpuru / Andrés Lira González (eds.), México-, 1808-1821. Las ideas y los hombres, México: El Colegio de México, 2014, pp. 23-24, 43; Horst Pietschmann, "Los principios rectores de organización estatal en las Indias": Antonio Annino / Luis Castro Leiva / François-Xavier Guerra (eds.), De los imperios a las naciones. Iberoamérica, Zaragoza: Ibercaja Obra Cultural, 1994, pp. $79,88,102$.

10 Según Thomas Calvo, "Ciencia, cultura y política ilustradas (Nueva España y otras partes)”: Clara García Ayluardo (ed.), Las reformas borbónicas. 1750-1808, México: Fondo de Cultura Económica, 2010, ubicación 1161, Kindle; la meta de las reformas ilustradas de 1787-1790 incluso era "unión e igualdad", lo que amenazó la identidad gobernativa de América; mientras García Ayluardo, "Re-formar la

Jahrbuch für Geschichte Lateinamerikas | Anuario de Historia de América Latina 
estudiado estoy de acuerdo en que esas reformas no discriminaron sistemáticamente a los grupos criollos, ya que comprendieron a los antiguos partidarios de un virrey reformista que tenían diversas procedencias regionales, incluso peninsulares.

Al mismo tiempo, otra tendencia amplia la mirada a los períodos anteriores a la visita de Gálvez. Allan Kuethe y Kenneth Andrien sostienen, por ejemplo, que durante una fase que abarca desde finales de 1730 hasta 1754, el gobierno rompió el poder del consulado de Cádiz, expandió los navíos registrados, terminó con las recaudaciones privadas de impuestos en España, y cesó la venta de nombramientos de cargos. Los dos académicos también subrayan los fracasos de Gálvez, a quien culpan de las grandes revueltas en el altiplano andino (17801782) y de los disturbios en la Nueva España durante la visita general. ${ }^{11}$ Ellos y otros expertos, por lo tanto, reconocen plenamente la importancia de las reformas de Ensenada desde 1745, que según otros académicos se asemejaban a las de Gálvez en sus medidas, ${ }^{12}$ porque Ensenada remodeló con éxito la administración financiera, que incluso Carlos III dejó intacta, ${ }^{13}$ y reforzó considerablemente la marina con más de 85 buques de guerra, alcanzando "la plenitud del despotismo ilustrado español”.14 Además, Ensenada y Revillagigedo mandaron la

Iglesia novohispana", García Ayluardo (ed.), Las reformas borbónicas, ubicación 3980, Kindle, muestra el "proceso mulitifacético" reformador en el ámbito eclesiástico, véase también ubicación 4291, Kindle.

${ }^{11}$ Allan J. Kuethe / Kenneth J. Andrien, The Spanish Atlantic World in the Eighteenth Century. War and the Bourbon Reforms. 1713-1796, Cambridge: Cambridge University Press, 2014, pp. 3-6, 25, 348-350, 275-278. Antes, Bertrand, Grandeur, pp. 291, 325, ya aboga por la "long durée" de las reformas en virtud de que, durante la visita de Gálvez, concluyó una época de visitas y con la llegada de los intendentes comenzó otra.

${ }^{12}$ Adrian J. Pearce, The Origins of Bourbon Reform in Spanish South America. 17001763, New York: Palgrave Macmillan, 2014, pp. 10-14, 152-169. Según Francisco Eissa-Barroso, The Spanish Monarchy and the Creation of the Viceroyalty of New Granada (1717-1739). The Politics of Early Bourbon Reform in Spain and Spanish America, Amsterdam: Brill, 2016, p. 10, las reformas de principios de siglo no fueron "más vigorosas, de gran alcance o 'coloniales'" que las posteriores.

13 Renate Pieper, La Real Hacienda bajo Fernando VI y Carlos III (1753-1788). Repercusiones económicas y sociales, Madrid: Instituto de Estudios Fiscales, 1992, pp. 12, 62-64, 80-82.

14 José Luis Gómez Urdáñez, Fernando VI, Madrid: Arlanza, 2001, pp. 81, 105, cita en p. 144. 
secularización de más de cien doctrinas en pueblos indígenas que las órdenes regulares tenían que entregar al clero secular novohispano. ${ }^{15}$

Mi intento aquí no es comparar sistemáticamente el período de Ensenada y la visita general de Gálvez, sino más bien coincidir con las interpretaciones que señalan la importancia de ambas fases. Las iniciativas de los ministros redujeron el orden corporativo de la Nueva España y fortalecieron el poder monárquico. Como he discutido en la introducción de este dosier, el Imperio español transitaba poco a poco hacia un estado más unificado. Sin embargo, mientras que las reformas de Revillagigedo avanzaban sin notable revuelta local, la expulsión y otras medidas de Gálvez se volvieron más conflictivas. Claramente, las causas de los disturbios o de la falta de ellos eran múltiples y también locales. Por ejemplo, en 1767 el gobernador indígena de Pátzcuaro envió circulares a otros pueblos para resistir al exilio de los jesuitas, mientras que Tzintzuntzan rechazó la colaboración, porque aún se dolía por el traslado de la capital a Pátzcuaro en $1539 .{ }^{16}$ No obstante, el hecho de que Croix y Gálvez atacaran a un grupo de antiguos clientes virreinales, que hasta el fallecimiento de Revillagigedo el 27 de noviembre de 1766 gozaron de buenas conexiones con la corte en Madrid, contribuyó a la acrimonia. ${ }^{17}$

\section{Revillagigedo e Ignacio Cevallos quitaron la alcabala al Consulado de México}

Ensenada, quien nombró virrey a Revillagigedo, forjó una coalición que incluía a varios influyentes jesuitas. El propio Ensenada se desempeñó como secretario de tres principales materias: la de Real Hacienda, la de Guerra, y la de Marina e Indias. Colaboró estrechamente con el confesor del rey, el jesuita Francisco Rávago y Noriega (1685-1763), quien actuó

\footnotetext{
15 Christoph Rosenmüller, “'The Indians... long for change'. The Secularization of Regular Parishes in New Spain, 1749-1755”: Francisco A. Eissa-Barroso / Ainara Vázquez Varela (eds.), Early Bourbon Spanish America. Politics and Society in a Forgotten Era, Leiden: Brill, 2013, pp. 143-164.

16 Castro Gutiérrez, Nueva ley, pp. 168-170, 237-238.

${ }^{17}$ Sobre la fecha del fallecimiento de Revillagigedo, ver del Valle Menéndez, Güemes, pp. 660-665.
} 
como virtual ministro de asuntos religiosos y protegió a la Compañía de Jesús en un momento en que sus enemigos se fortalecieron. ${ }^{18}$

En la Nueva España, Ignacio Cevallos llegó a ser el asesor de mayor confianza de Revillagigedo en asuntos de la Real Hacienda. Cevallos nació en Santiago de Guatemala, hijo de María Josefa de Uría y Manuel de Cevallos y Villagutierre, alcalde mayor de Sonsonate en El Salvador. Sus padres eran originarios de Béjar, cerca de Salamanca, en León, España; también era sobrino de un presidente de la audiencia de Guatemala. ${ }^{19}$ Cevallos se educó en un colegio jesuita y en la Universidad de México, donde fue becario del colegio mayor de Santa María de Todos Santos. Se convirtió en prebendado de rango inferior (medio racionero) en la Catedral de México. Luego viajó a España para solicitar una canonjía, la cual obtuvo en 1746. Regresó a la Nueva España en 1748. Al año siguiente, el arzobispo lo nombró juez visitador de testamentos, capellanías y obras pías, y llegó a ser tesorero de la Catedral en 1750. La colaboración de Revillagigedo con Cevallos también indica que, en cierta medida, el virrey se vinculó con grupos projesuitas, tal como lo hizo Ensenada en Madrid. ${ }^{20}$

18 José Luis Gómez Urdáñez, "Carvajal y Ensenada. Un binomio político": José Miguel Delgado Barrado / José Luis Gómez Urdáñez (eds.), Ministros de Fernando VI, Córdoba: Servicio de Publicaciones, Universidad de Córdoba, 2002, p. 68; Gómez Urdáñez, Fernando VI, p. 85; Juan Luis Castellano, Gobierno y poder en la España del siglo XVIII, Granada: Universidad de Granada, 2006, p. 154; Diego Téllez Alarcia, "Guerra y regalismo a comienzos del reinado de Carlos III. El final del ministerio Wall": Hispania, 3: 209 (2001), p. 1079, sostiene que Ensenada se basó en los jesuitas y los colegiales mayores; sobre Rávago y Noriega, ver Iván Escamilla González, "Los confesores reales de España en la época borbónica y su intervención en la política americana de la monarquía. El caso de Francisco de Rávago, SJ, confesor de Fernando VI": Francisco Javier Cervantes Bello / María del Pilar Martínez López-Cano (eds.), La dimensión imperial de la Iglesia novohispana, México: UNAM / BUAP, 2016, pp. 234, 241-247.

19 Agradezco a Udo Grub por su perspicaz comunicación acerca de los orígenes guatemaltecos de Cevallos. Según él y la real cédula firmada por José de Veytia Linage, Madrid, 19 de noviembre de 1678, AGI, Guadalajara 89, el tío era Alonso de Cevallos y Villagutierre, que se desempeñó como presidente de la audiencia de Guadalajara desde 1679 hasta enero de 1702. Luego sirvió de presidente de la audiencia de Santiago de Guatemala, donde falleció el 27 de octubre de 1703.

20 Consulta de la Cámara de las Indias, Madrid, 17 de febrero de 1746, con la resolución del rey adjunta, AGI, México 438; Ensenada (probablemente) a Rubalcava, Madrid, 10 de octubre de 1747, y Francisco de Varas y Valdés a 
Revillagigedo recomendó a Cevallos ante la Corona en 1749, pero su cada vez más estrecha cercanía con el canónigo también levantaba algunas sospechas en Madrid. ${ }^{21} \mathrm{El}$ fiscal del Consejo de Indias criticó al "D[oct]or Cevallos, de quien el Virrey se vale para su formación, a que no puede atender por sus muchos negocios, avanzada edad, y falta de salud."22 No obstante, el canónigo también contaba con partidarios en Madrid, tales como el oficial mayor de la secretaría de Marina e Indias, José Banfi y Parrilla, hechura de Ensenada. Los orígenes de las amistades y animadversiones madrileñas de Cevallos son desconocidos; pero, en 1751, el virrey y el oficial mayor respaldaron una nueva promoción para Cevallos. Rávago y Noriega, el confesor del rey, sin embargo, la objetó. Banfi y Parrilla escribió a Revillagigedo que

"Cierto es el mérito de nuestro Cevallos y lo bien que recayera en el la tesorería, resistencia hubo bastante, fui de[...] mi Xefe [Ensenada] a ver al Padre Confesor, le hablé en su nombre; se lo pedí en el mío también, y le manifesté la recomendación eficaz de Vuestra Excelencia, tuvimos varia y larga discusión y argumentos, y al día siguiente me dijo, en tono bastante displicente ya tiene Vuestra Merced a su Cevallos tesorero. En la actual constitución tengo por muy difícil que aun que se repitieran las ocasiones, adelantaremos otro paso".23

A cambio del patronazgo, Cevallos aconsejó al virrey en su estrategia para recuperar la administración de la alcabala. Ése fue uno de los logros más importantes de Revillagigedo durante su virreinato. Desde 1745 , el consulado pagaba a la corona 373,333 pesos anuales por el derecho de cobrar la alcabala de México. El gobierno recibió informes de que el consulado se embolsaba cantidades considerables de dinero

Ensenada, Cádiz, 13 de noviembre de 1747, ambos documentos, en AGI, México 1849; título de nombramiento, Buen Retiro, 14 de Marzo de 1750, AGI, México 442; el arzobispo Manuel Rubio y Salinas al rey, México, 28 de noviembre de 1749, AGI, México 807; relación de méritos de Cevallos, sin fecha, AGI, Indiferente, 224, N. 82.

${ }^{21}$ Resumen de la recomendación de Cevallos por Revillagigedo, México, 16 de julio de 1749, AGI, Indiferente, 224, N. 82; véase también real cédula a Revillagigedo, Aranjuez, 12 de mayo de 1751, Archivo General de la Nación [AGN], Reales Cédulas Originales [RCO], 71, exp. 122, fol. 363. Pearce, Origins, pp. 160-162, muestra que el virrey conde de Superunda también confiaba en un tesorero catedralicio criollo.

22 Respuesta del fiscal del Consejo de Indias, Madrid, 19 de mayo de 1754, AGI, México 516.

23 José Banfi y Parrilla a Revillagigedo, Madrid, 4 de septiembre de 1751, ACR, 388. 
de la recaudación y podía pagar una cantidad significativamente mayor. Cuando se agotó el período contractual de la renta, Ensenada ordenó a Revillagigedo que se incautara la alcabala contra la aguda protesta del consulado. Los oficiales reales comenzaron su recolección, y la recaudación anual de la corona se disparó a 739,056 pesos en 1754 y 738,792 pesos en 1755. En 1776 el consulado aún poseía más de un millón de pesos en un fondo clandestino que había obtenido durante su gestión, lo que demuestra la importancia de esos ingresos. El consulado sufrió un serio golpe financiero, y el éxito de Revillagigedo allanó el camino para las subsecuentes terminaciones de contratos de muchas recaudaciones privadas en las provincias, aunque el control total del Estado de las alcabalas llegaría hasta $1776 .{ }^{24}$

El consulado defendió ferozmente la rentable administración, y atacó a Revillagigedo por ignorar el asesoramiento de experimentados funcionarios. Desde su punto de vista, Revillagigedo pasó por alto sus argumentos porque "no se hizo cargo el virrey en su decreto, porque no los tendría presentes, los unos por olvido, y los otros por falta de noticia de la persona que consultó para el proyecto“. Esta persona fue Ignacio Cevallos, quien, en opinión del consulado, era un

"sujeto de ninguna inteligencia en el gobierno, y mucho menos en el asunto de alcabalas de esta ciudad por haber nacido en la Provincia de Guatemala, distante trescientas leguas, y haber estado en México de tránsito, sin manejo alguno de negocios ni motivos". ${ }^{25}$

${ }^{24}$ Fabian de Fonseca / Carlos de Urrutia, Historia general de real hacienda. Por orden del virey, conde de Revillagigedo. Obra hasta ahora inedita y que se imprime con permiso del supremo gobierno, México: V. G. Torres, 1849, tomo 2, pp. 29-51, y entre pp. 119 y 120. Según Stein / Stein, Silver, Trade, and War, p. 240, nota 45, "los ingresos tributarios de Nueva España crecieron en un 123 por ciento a partir de 1754". Sobre los fondos de 1776, véase Guillermina del Valle Pavón, Donativos, Préstamos y Privilegios. Los Mercaderes de la Ciudad de México durante la Guerra Anglo-Española de 1779-1783, México: Instituto Mora, 2016, p. 29; Ernest Sánchez Santiró, "La hacienda reformada. La centralización de la renta de alcabalas en Nueva España (1754-1781)": Luis Jáuregui / Antonio Ibarra (eds.), Finanzas y política en el mundo iberoamericano. Del antiguo régimen a las naciones independientes, México: Universidad Autónoma del Estado de Morelos / Instituto Mora / UNAM, 2001, pp. 145-158.

25 Consulado al rey, México, 1 de marzo de 1754, AGI, México 2093; véase también, del cabildo al rey, México, 22 de diciembre de 1753, AGI, México 2093. 
Peor aún, Cevallos era amigo del comerciante Juan Bautista Belaunzarán ${ }^{26}$ y de Crisóstomo de Barroeta, el regente del Tribunal de Cuentas, quienes se enfrentaron a un conflicto de intereses en esta cuestión. ${ }^{27}$ El consulado afirmó que Barroeta estaba en componenda con Belaunzarán "por estar casados los dos, con dos hermanas". El grupo incluía también a una tercera hermana y su marido, así como al rico comerciante Jacinto Martínez de Aguirre. El colmo era, según el consulado, "considerarse todos comprehendidos, e interesados en la postura, que se hizo en Madrid, a nombre de Belaunzarán" de la administración de la alcabala. ${ }^{28}$

Revillagigedo incluyó en su familia ritual tanto a Martínez de Aguirre como al conde de San Bartolomé de Xala, e Ignacio Cevallos participó en algunas funciones. El hijo mayor de Revillagigedo, Juan Vicente, ofició como padrino en la inducción de Jacinto Martínez de Aguirre a la orden de Calatrava el 20 de julio de 1754, aunque Martínez de Aguirre era 32 años mayor que Juan Vicente. ${ }^{29}$ Mientras tanto, el conde de San

26 Consulado al rey, México, 1 de marzo de 1754, AGI, México 2093.

27 Barroeta apoyó a Revillagigedo en el juicio de residencia; testimonio, México, 17 de enero de 1757, AGI, Escribanía 246 B, fol. 27v; ver las cartas de Barroeta a Revillagigedo, México, 23 de junio de 1761 y 1 de julio de 1761, ACR, 404; consulado a Manuel Álvarez de Toledo, México, 11 de marzo de 1754, AGI, México 2501. Revillagigedo a Ensenada, México, 23 de enero de 1752, AGI, México 1506, núm. 109, indica que Barroeta era el hermano del arzobispo de Lima.

28 Las dos anteriores citas en consulado al rey, México, 1 de marzo de 1754, AGI, México 2093.; testimonio de Cosuela, México, 12 de septiembre de 1750, AGI, Escribanía 217 A, cuaderno 2, fol. 9; Javier Sanchiz / José Ignacio Conde Díaz Rubín, "La familia Monterde y Antillón en Nueva España. Reconstrucción genealógica (primera parte)": Estudios de Historia Novohispana, 32 (2005), pp. 99-100, 115-116; las tres hermanas Monterde Antillón provenían de una influyente familia de comerciantes. María Ignacia Rodríguez de Vargas Monterde y Antillón se casó con Juan Crisóstomo Barroeta, su hermana Ignacia Margarita lo hizo con Juan Bautista Belaunzarán, y María Josefa, con Manuel Cosuela, ver también Jacinto Martínez de Aguirre, México, 3 de enero de 1744, AGN, Historia 120, exp. 13.

${ }^{29}$ Según del Valle Menéndez, Güemes, p. 328, Juan Vicente de Revillagigedo y Padilla nació el 20 de abril de 1736 en La Habana, Cuba, mientras que Martínez de Aguirre declaró en su testimonio, México, 3 de enero de 1743, AGN, Historia de 120, exp. 13, que tenía 40 años; AGN, Bienes Nacionales [BN] 53, exp. 14n; véase depósito irregular del consulado de México, 18 de febrero de 1743, AGN, Judicial 21, exp. 67, fols. 116v-118; real cédula a la audiencia, San Ildefonso, 15 de agosto de 1742, 
Bartolomé de Xala, quien era tal vez el comerciante más rico de México de la época, importaba cacao venezolano e invertía en una cadena de haciendas pulqueras. ${ }^{30}$ Joaquín de Castro Santa-Ana, el autor de un diario contemporáneo, informó que, en la tarde del 21 de diciembre de 1752 ,

"se bautizó en el Sagrario de esta santa iglesia la hija primogénita de Don Alonso Antonio Gómez de la Bárcena, secretario de cámara y gobierno del Exelentísimo Señor virrey [...] y de Doña Josefa Rodriguez Sans de Pedrozo Soria y Villaroel; a la que pusieron por nombre Antonia Josefa María de la Concepción Rafaela Abina Tomasa de Jesús; echóle el agua el Dr. Don Ignacio de Cevallos, actual juez de testamentos y tesorero de esta santa iglesia, y de brazos fue padrino el señor coronel Don Juan Vicente Güemez Horcasitas y Padilla, capitán de la real guardia de caballería, hijo primogénito del expresado Exelentísimo Señor virrey [...] la concurrencia fue grande, el dinero que se repartió a los pobres con esplendidez, el refresco ostentoso, por haber concurrido los principales sugetos de esta ciudad." 31

Los comerciantes cercanos a Cevallos compartían lazos familiares, y algunos de ellos tenían intereses en varios rubros (o ramas) de la recaudación hacendaria de la tesorería real. El grupo existía al menos desde principios de la década de 1740, ya que el virrey Fuenclara había colaborado en cierta medida con éste, lo que preocupaba a Madrid. En 1744 Ensenada ordenó que un inquisidor informara secretamente sobre

AGN, RCO, 62, exp. 57, fols. 170-179v; Castro Santa-Anna, Diario, vol. 5, p. 15. Revillagigedo a Julián de Arriaga, México, 20 de octubre de 1755, ACR, 404.

30 Manuel Rodríguez Sáenz Pedrozo se casó con Josefa Soria Villarroel y Berduzco y obtuvo el título de conde de San Bartolomé de Xala en 1749; Castro Santa-Anna, Diario, vol. 4, p. 35. Edith Boorstein Couturier, The Silver King. The Remarkable Life of the Count of Regla in Colonial Mexico, Albuquerque: New Mexico Press, 2003, p. 70; Doris M. Ladd, The Mexican Nobility at Independence 1780-1826, Austin: University of Texas Press, 1976, p. 199; John Tutino, Creole Mexico. Spanish Elites, Haciendas, and Indian Towns, 1750-1810, Austin: University of Texas, 1976, p. 64 (tesis de doctorado); Guillermina del Valle Pavón, "Relaciones de negocios, familiares y de paisanaje de Manuel Rodríguez de Pedroso, Conde de San Bartolomé de Xala, 1720-1770": Guillermina del Valle Pavón / Antonio Ibarra (eds.), Redes Sociales e instituciones comerciales en el Imperio español, siglos XVII a XIX, México: Instituto Mora / UNAM, 2007, pp. 117-141.

31 Castro Santa-Anna, Diario, vol. 4, pp. 58-59. 
"Don Juan Crisóstomo de Barroeta, Don Manuel de Cosuela y un mercader llamado Don Jacinto Martínez [de Aguirre], exponiendo Vuestra Señoría igualmente lo que supiere del porte y conducto de estos sujetos". 32

Crisóstomo Barroeta, por ejemplo, era el tipo de funcionario de quien Revillagigedo sospechaba de una mala conducta. Barroeta originalmente se ganaba la vida como comerciante y compró varios nombramientos para alcaldías mayores. En 1740 pagó para obtener el nombramiento como regente del Tribunal de Cuentas. En su reporte de 1748, Revillagigedo notó que en

"todos estos individuos que asisten al despacho, las cuentas corrientes, y expedientes de él, no tienen aquel puntual breve curso que debieran [...] se me presenta la dificultad, e inconveniente de las mercedes, que S[u] M[ajestad] ha hecho a los Min[ist]ros de este tribunal por las gruesas cantidades con que le han servido, y los premios, y gastos a que se grabaron para su contribución". 33

Sin embargo, hacia 1752, Revillagigedo elogió la diligencia de Barroeta y lo recomendó - como uno de las dos únicos novohispanos que no eran juristas - a un prestigioso escaño en el Consejo de Indias. ${ }^{34} \mathrm{Al}$ menos en algunos otros casos Revillagigedo confió en este grupo. El conde de San Bartolomé de Xala, por ejemplo, fue parte del cabildo de México y se abstuvo de votar cuando el cabildo falló a favor de enviar un agente a Madrid para oponerse a las medidas del virrey en el asunto de la alcabala. ${ }^{35}$

La coalición de Revillagigedo estaba integrada por personas que recientemente habían migrado a la Nueva España, en su mayoría provenientes del norte de España. Éstos estaban dispuestos a ayudar al virrey y beneficiarse de su patrocinio, tal como vimos en el caso de Cevallos. Belaunzarán y Cosuela, por ejemplo, provenían de las provincias vascas y Barroeta de La Rioja. Martínez de Aguirre y San Bartolomé de Xala también emigraron del norte de España. El propio Revillagigedo creció en Asturias, en el norte de España. Ignacio Cevallos

32 Ensenada a Pedro Navarro, Aranjuez, 25 de mayo de 1744, AGN, Inquisición 1328, exp. 6, fol. 239.

33 Informe de Revillagigedo a Ensenada, México, 30 de enero de 1748, AGI, México 1506, núm. 40.

34 Ibidem.

${ }^{35}$ Sesiones extraordinarias del cabildo del 21, 26, 31 de mayo y del 11 y 14 de junio de 1755, Archivo Histórico de la Ciudad de México, Actas del cabildo 79 A, fols. 5272. 
era la excepción en el sentido de haber nacido en Guatemala, aunque también había llegado a la Nueva España hacía poco tiempo.

\section{Aliados cercanos de Revillagigedo durante el conflicto de la alcabala}

\begin{tabular}{|l|l|l|l|}
\hline \multicolumn{1}{|c|}{ Nombre } & \multicolumn{1}{|c|}{ Origen } & $\begin{array}{l}\text { Arribo a Nueva } \\
\text { España }\end{array}$ & $\begin{array}{l}\text { Relación con el } \\
\text { consulado }\end{array}$ \\
\hline $\begin{array}{l}\text { J. Crisóstomo } \\
\text { Barroeta }\end{array}$ & La Rioja & 1723 & \\
\hline $\begin{array}{l}\text { Juan Bautista } \\
\text { Belaunzarán }\end{array}$ & $\begin{array}{l}\text { Vasco } \\
\text { (Guipúzcoa) }\end{array}$ & $\begin{array}{l}\text { Mediados de la } \\
\text { década de } \\
1720\end{array}$ & $\begin{array}{l}\text { Guatemala, } \\
\text { padres eran } \\
\text { originarios de } \\
\text { Salamancalos } \\
\text { Villagutierre }\end{array}$ \\
\hline $\begin{array}{l}\text { (León) } \\
\text { Manuel } \\
\text { Cosuela y } \\
\text { Echavarri }\end{array}$ & $\begin{array}{l}\text { Vasco } \\
\text { (Vizcaya) }\end{array}$ & 1723 & $\begin{array}{l}\text { Miembro en } \\
1761\end{array}$ \\
\hline $\begin{array}{l}\text { Jacinto } \\
\text { Martínez de } \\
\text { Aguirre }\end{array}$ & Vasco & $\begin{array}{l}\text { Cónsul en } \\
1743\end{array}$ \\
\hline $\begin{array}{l}\text { Manuel } \\
\text { Rodríguez } \\
\text { Sáenz Pedrozo, } \\
\text { Conde de San } \\
\text { Bartolomé de } \\
\text { Xala }\end{array}$ & La Rioja & $\begin{array}{l}\text { Diputado del } \\
\text { consulado en } \\
1736, \text { cónsul } \\
1739-1740, \\
\text { prior en 1759 }\end{array}$ \\
\hline
\end{tabular}

Fuentes: Sanchiz, "Familia Monterde”, pp. 101-102, 115-118; Tutino, Creole Mexico, pp. 62-81; véanse también las notas 19-21, 27-28.

Ahora bien, no se puede considerar, en ningún sentido que el grupo de Revillagigedo fuera opositor al consulado. Es incluso probable que este grupo formara una facción dentro del consulado, la cual fue temporalmente excluida de los puestos influyentes. Por ejemplo, tanto Martínez de Aguirre como San Bartolomé de Xala ocuparon posiciones 
de liderazgo en el consulado, si bien antes o después del periodo de Revillagigedo. San Bartolomé de Xala fue cónsul entre 1739 y 1740, mientras que Martínez de Aguirre ocupó ese cargo en 1743. El comerciante Cosuela actuó como miembro en $1761 .{ }^{36}$

Con todo, el mandato de Revillagigedo llegó a su fin cuando Ensenada cayó del poder el 21 de julio de 1754. El rey Fernando VI temía que Ensenada, al adoptar una postura más agresiva contra los asentamientos ingleses en el Caribe, lo hubiera traicionado y escuchaba con mayor frecuencia las demandas de la oposición. El gobierno más conservador de Ricardo Wall reemplazó a Ensenada, y la Corona pronto separó a Revillagigedo de la Nueva España, tierra que dejó el 9 de noviembre de 1755; lo sucedió el marqués de las Amarillas. Casi al mismo tiempo, en la Nueva España se puso en marcha el juicio de residencia para investigar la conducta de Revillagigedo durante su mandato. Para esta tarea, la Corona designó a un recién nombrado oidor de la audiencia de Guadalajara. Cuando éste llegó a la Ciudad de México para iniciar el proceso, rápidamente entabló relaciones cordiales con los aliados de Revillagigedo, entre ellos Ignacio Cevallos y el oidor Domingo de Valcárcel, quienes se desvivieron por atenderlo. El 18 de diciembre ${ }^{37}$

"llegó a este capital Don Francisco Galindo juez de residencia del pretérito inmediato virrey; y saliendo a su recibimiento a Guadalupe, Cevallos por amistad [...] El aspecto, y el modo prometen buenas prendas de ánimo, y habiéndosele puesto la casa contigua al Espíritu Santo por el Conde de [San Bartolomé de] Xala, y su yerno, ha sido cumplimentado por lo más distinguido de la Ciudad. El primero día comió con Cevallos, acompañado de los tres que se refieren, y Martínez [de Aguirre]. El 28 de diciembre: convido a comer al juez de residencia

36 Del Valle Pavón, Donativos, pp. 29-33; Rosenmüller, Patrons, iluminan peleas al interior del consulado.

37 De acuerdo con Revillagigedo a Arriaga, México, 12 de junio de 1755, ACR, 455; Revillagigedo a Arriaga, México, 14 de junio de 1755, ACR, 455; Revillagigedo a Ensenada, México, 30 de enero de 1748, AGI, México 1506, núm. 40; Revillagigedo a Ensenada, México, 23 de enero de 1752,AGI, México 1506, núm. 109; Instrucción de Revillagigedo a Amarillas, México, 28 de noviembre de 1754, AGI, México 1506, núm. 167a; Revillagigedo dio al oidor Domingo de Valcárcel Formento y Vaquerizo varias comisiones a comienzos de la década de 1750, lo nombró auditor de guerra y recomendó a su hijo para ser prebendado en la catedral de México. El virrey finalmente llamó a Valcárcel para que lo defendiera en el juicio de residencia, importante tarea que a menudo se otorgaba a amigos de confianza. 
Galindo el oidor Valcárcel, y con este motivo concurrieron también otros de la ropa para obsequiarlo, porque su buen modo lo ha hecho insinuar benévolamente con todos".38

La mayoría de los miembros de la alianza continuaron comunicándose con Revillagigedo después de su regreso a España, con la esperanza de recibir algún tipo de patronazgo. Con frecuencia Revillagigedo escribió a Ignacio Cevallos,39 en 1762 se dirigió al canónigo como su "querido amigo" y le pidió: "haga mis afectuosísimas expresiones a mi Conde de San Bartolomé [de Xala], Don Alfonso [Gómez de Bárcena], el Regente [Crisóstomo de Barroeta], [Manuel] Cosuela".40 Algunos de estos vínculos lograron transmitirse a la siguiente generación. Entre 1763 y 1764, Revillagigedo también afirmó su amistad con el hijo de Belaunzarán. ${ }^{41}$ Adicionalmente, el hijo de Jacinto Martínez de Aguirre escribió en 1763 que la Corona se había apoderado del monopolio del pulque, y sostuvo que la familia había perdido la mayor parte de su fortuna tras la muerte de su padre, por lo que buscó que Revillagigedo lo ayudara en la corte. ${ }^{42}$

38 Documento titulado Papeleta de México de 25 de noviembre de 1756 hasta el 9 de enero de 1757, ACR 360; véase también la real cédula, Aranjuez, 6 de julio de 1755, AGI, Escribanía 246 A, cuaderno 1, fols. 1-3; cargo en contra de Revillagigedo, 1757, AGI, Escribanía 246 A, cuaderno 5, fols. 1-3; refutación de Baltasar Rodríguez Medrano, México, ibidem, fols. 27-28v; sentencia de Galindo, México, 6 de junio de 1757, ibidem, fols. 34-50v.

${ }^{39}$ Revillagigedo a Cevallos, 9 de febrero de 1762; Cevallos a Revillagigedo, Madrid, 5 de abril de 1763, ambas cartas en ACR 404; cartas de Cevallos a Revillagigedo, México, 4 de mayo de 1762, 12 de abril de 1763, y 30 de abril de 1763, y Revillagigedo a Cevallos, Madrid, 9 de octubre de 1763, todas las cartas en ACR 396.

40 Revillagigedo a Cevallos, Madrid, 7 de diciembre de 1762, ACR, 388; Revillagigedo a Manuel Cosuela, Madrid, 5 de abril de 1763, ACR, 388; Belaunzarán a Revillagigedo, México, 13 de julio de 1761, ACR, 344; Manuel Cosuela a Revillagigedo, México, 2 de diciembre de 1761, ACR 387.

${ }^{41}$ Revillagigedo a Juan Bautista Belaunzarán, Madrid, 1 de julio de 1763, ACR, 387; Belaunzarán a Revillagigedo, México, 1 de diciembre de 1764, ibidem. Según Sanchiz, "La familia Monterde", p. 102, el padre Juan Bautista Belaunzarán murió en México el 14 de junio de 1762.

42 Juan Martínez de Astiz a Revillagigedo, México, 20 de abril de 1763; véase también, por ejemplo, Manuel de Rivas Cacho a Revillagigedo, México, 27 de abril de 1763, ambos documentos en ACR 396; de acuerdo con la copia del decreto del virrey marqués de Cruillas, sin lugar, 17 de septiembre de 1762 y la copia de la 


\section{Supresión de la clientela projesuita de Revillagigedo}

Tras su regreso a España, Revillagigedo desempeñó un influyente papel en la corte, a pesar de sus estrechos vínculos con el desprestigiado marqués de la Ensenada. El otrora virrey fue nombrado capitán general de Castilla la Vieja en $1756 .{ }^{43}$ Su reputación creció todavía más cuando el rey Carlos III ascendió al trono en 1759 y nombró al marqués de Esquilache como secretario de finanzas en 1763 y a Revillagigedo, virrey de Navarra. Poco después, el rey cambió de parecer y lo nombró decano del Consejo de Guerra en Madrid. Revillagigedo había impresionado al monarca con su trayectoria exitosa y, entre otros servicios, con el cambio de poderes sin incidentes en la alcabala de México. El antiguo virrey se convirtió en un importante asesor de la Corona, al grado de que, según un testimonio, el rey escuchaba "todas las propuestas relativas a América por el $\mathrm{M}$. de [Güemes y] Horcasitas". ${ }^{4}$ Éste oficial de alto rango proveniente de la baja nobleza y con 22 años de experiencia en ultramar, ascendió al escalafón superior del gobierno.

En 1766 el motín de Esquilache terminó esta fase política y marcó el fin de la Compañía de Jesús en el imperio. La causa inmediata del levantamiento se dio cuando Esquilache prohibió los sombreros grandes y las capas largas que eran de uso común en Castilla. Su objetivo era modernizar el código vestimentario y dificultar la ocultación de armas ilegales entre la población. Además, el gobierno eliminó los límites de precios en el comercio de cereales para estimular la oferta, pero una sequía provocó un notable aumento de los precios. Entre el 21 y el 26 de marzo, opositores - tanto del pueblo como de la élite-

representación de Cruillas a Arriaga, México, 9 de abril de 1763; Cruillas retrasó el final de los negocios pulqueros de Martínez de Aguirre y apoyó la petición del comerciante para conservar su negocio.

43 Véase, por ejemplo, la orden de Eslava a Revillagigedo para que convocara una junta de generales a fin de discutir el calibre de los cañones, Buen Retiro, 9 de mayo de 1757, ACR 395; Francisco A. Eissa Barroso, Politics, Political Culture, and Policy Making. The Reform of Viceregal Rule in the Spanish World under Philip V. (1700-1746), Coventry: University of Warwick, 2010, p. 246, nota 229 (tesis de doctorado).

44 P. Béliardi, cónsul-general francés en España a Nicolas-René Berryer, secretario de la marina francesa, citado en Stein y Stein, Apogee, p. 13. Sobre la caída de Wall, véase también Revillagigedo a Cevallos, Madrid, 9 de octubre de 1763, ACR, 396. 
unieron sus fuerzas y se rebelaron. Exigían la reducción del precio de granos, la dimisión de Esquilache, la expulsión de los guardias extranjeros, y la derogación del código vestimentario. En uno de sus últimos actos políticos, Revillagigedo participó en una junta formada con el propósito de responder a la revuelta. Mientras que algunos integrantes de esta junta eran partidarios de una posición dura frente a los opositores, Revillagigedo y la mayoría de sus integrantes abogaban por hacer concesiones. Carlos III temió por su vida, aceptó públicamente la mayoría de las demandas, declaró un perdón general y despidió a Esquilache. Después, el rey huyó de Madrid a Aranjuez en la noche del 24 de marzo. Poco más tarde, Revillagigedo se retiró del Consejo de Guerra y falleció. En seguida, Carlos III y sus asesores culparon a la Compañía de Jesús por el motín. La compañía había sido, durante mucho tiempo, una piedra en el zapato de la monarquía. Se rehusó, por ejemplo, a pagar el diezmo de las frutas de sus haciendas a la iglesia secular en América. Como consecuencia, el 27 de febrero de 1767, el rey ordenó expulsar a los jesuitas de todos los reinos españoles. ${ }^{45}$

En su último año en el cargo, el gobierno de Esquilache nombró a José de Gálvez como visitador general de la Nueva España. Gálvez y Croix provocaron a muchos novohispanos porque impusieron recaudaciones más rigurosas sin ofrecer mucho a cambio. Gálvez también obedeció las órdenes de Madrid y expulsó a los jesuitas de la Nueva España el 25 de

45 Stein / Stein, Apogee, pp. 83-107, señalan a los cabecillas del Consejo de Castilla y a su gobernador, el obispo de Cartagena Diego de Rojas y Contreras y a otras facciones privilegiadas que derrocaron a Esquilache con apoyo popular; Kuethe / Andrien, Atlantic World, pp. 262-266, 272-273. Mientras tanto, José Miguel López García, El motín contra Esquilache. Crisis y protesta popular en el Madrid del siglo XVIII, Madrid: Alianza Editorial, 2006, pp. 13-14, 237-239, hace hincapié en el origen popular de la revuelta-especialmente entre criados, peones de construcción, y mozos de cuerda - y resta importancia al partido ensenadista, los jesuitas, la burguesía o la embajada francesa. Por su lado, José Andrés-Gallego, El motín de Esquilache, América y Europa, Madrid: Fundación Mapfre Tavera, CSIC, 2003, pp. 600-603, explica la revuelta como resultado de las maquinaciones de la élite contra Esquilache. Sin embargo, ambos historiadores también señalan que los dos aspectos estuvieron conectados. Las élites buscaron valerse de las clases populares - especialmente de su desasosiego acerca de los precios de alimentos, los impuestos y la prohibición de usar sus ropas de costumbre- a pesar de que no podían controlar sus demandas. 
junio de 1767. Tan sólo unas horas después de enterarse del decreto real, los jesuitas de la ciudad de México y los distritos aledaños se pusieron en marcha, entre ellos varias eminencias intelectuales, como Francisco Xavier Clavigero. Caminaron hasta el puerto de Veracruz, donde embarcaron para Europa. La corona mientras tanto embargó los colegios jesuitas en veintiún villas y ciudades. La ruina de la orden causó encono entre muchos novohispanos. Varios de ellos habían hecho generosas donaciones a las fundaciones Jesuitas, mismas que educaban a sus hijos. 46

Los disturbios comenzaron en San Luis Potosí a finales de junio de 1767. Los inconformes saquearon comercios, tomaron la armería, liberaron presos y frustraron el intento de expulsar a los jesuitas. La revuelta se extendió a Guanajuato, donde los mineros ocuparon las oficinas locales del estanco del tabaco y acabaron con la nueva administración de alcabalas. Poco después, una multitud de 8,000 personas defendió a los jesuitas. En Michoacán la población había protestado contra el nuevo gravamen militar desde agosto de 1766. A principios de 1767, el recién electo gobernador indígena de Pátzcuaro exigió la lealtad de más de cien pueblos subordinados, reminiscencia del antiguo reino tarasqueño, para resistir la expulsión de los ignacianos. Algunos acusaron al rey de ser hereje y demandaron exiliar a los españoles peninsulares. El visitador general y el ejército reprimieron el levantamiento y castigaron a los cabecillas. Ahorcaron a 85 personas, entre ellos el gobernador de Pátzcuaro, azotaron a otras 73 y enviaron a casi 800 sujetos a la cárcel o al exilio. ${ }^{47}$

Croix incluso llegó a detectar un "partido antigubernativo" en la Nueva España. Acusó al fiscal del crimen, Francisco Javier de Gamboa, y al fiscal de lo civil, Juan Antonio de Velarde y Cienfuegos, de publicar un libelo donde se atacaba la represión de la orden. También sugirió

46 García Ayluardo, "Re-formar", ubicación 4155, Kindle; Dorothy Tanck de Estrada / Carlos Marichal, "¿Reino o colonia? Nueva España, 1750-1804": Erik Velásquez García et al. (eds.), Nueva Historia general de México, México: El Colegio de México, 2010, pp. 313-314, 340.

47 Castro Gutiérrez, Nueva ley, pp. 115-208, 262-275; Kuethe / Andrien, Atlantic World, pp. 251-252, 269-271, 275-278; José Manuel Serrano Álvarez, "Croix, Carlos Francisco de": Real Academia de la Historia, Diccionario Biográfico electrónico [DBE, RAH], en línea: http://dbe.rah.es/ [12-10-2020]; Navarro García, "Destrucción", p. 14. 
despachar a los sospechosos a España y recomendó llamar a otros dos ministros de la audiencia, a tres miembros del cabildo catedralicio, a tres funcionarios de la administración financiera y al secretario virreinal. A medida que las indagatorias transcurrían, se mencionaron a otros tantos sospechosos. A fin de cuentas, 16 personas fueron acusadas de subvertir el gobierno, entre los que se encontraban cinco prebendados del cabildo catedralicio y cinco oficiales de la real hacienda.

Mientras la mayoría de los sospechosos se embarcó a España, la Corona apresó a tres de los presuntos conspiradores y los remitió al mismo destino, después de pasar por los calabozos de las fortalezas de San Juan de Ulúa, en Veracruz, y El Morro, en La Habana. No obstante, temeroso de la reacción que esto podía desencadenar en la Nueva España, Croix optó por tratar más gentilmente a la mayoría de los sospechosos. Se les ordenó trasladarse so pretexto de promoverlos a mejores posiciones en la península. Por otra parte, al oidor Diego Fernández de la Madrid se le permitió retirarse a un monasterio debido a su avanzada edad, mientras que a otros dos sospechosos también se les concedió permanecer en la Nueva España en atención a su edad o por enfermedad. 48

Ocho de los 16 sospechosos habían sido clientes de Revillagigedo o se beneficiaron de su patronazgo de forma significativa. Entre ellos estaban Ignacio Cevallos, por entonces arcediano de la catedral y su antiguo y confiable asesor, y Martín de Aspiroz, a quien Revillagigedo había nombrado oficial de la secretaría virreinal y contador supernumerario del Tribunal de Cuentas. Además, Revillagigedo había nombrado a Pedro Núñez de Villavicencio como superintendente de la Casa de Moneda de México y lo recomendó para una prestigiosa plaza en el Consejo de Indias. Otros clientes estaban vinculados con el virrey a través de dicho Cevallos, por ejemplo, Martín Crespo fungió como su capellán y el canónigo Antonio López Portillo era su primo. Por otro lado, ninguna de las personas que colaboraron con Revillagigedo en el

${ }^{48}$ Navarro García, "Destrucción", pp. 3-4, 7, 10-14; Brading, Miners, p. 39; Tanck de Estrada / Marichal, "Reino o colonia?", p. 315; Nancy Farriss, La Corona y el clero en el México colonial, 1579-1821. La crisis del privilegio eclesiástico, México: Fondo de Cultura Económica, 1968, p. 125; Herbert Ingram Priestley, José de Gálvez. Visitor-General of New Spain (1765-1771), Berkeley: University of California Press, 1916, p. 230. 
asunto de la alcabala, con la excepción de Cevallos, se encontró entre los desterrados; en parte porque tanto Martínez de Aguirre como Belaunzarán ya habían fallecido. Cevallos fue quien había apoyado firmemente la reforma de la alcabala y se opuso con vehemencia a Croix y Gálvez. ${ }^{49}$

Seis de los ocho clientes de Revillagigedo incriminados nacieron en el continente americano (siete si acaso también lo hubiera sido Martín Crespo), y cinco de ellos habían nacido o desempeñado sus funciones durante un lapso considerable en Guadalajara, Guatemala o Yucatán, es decir, fuera de la esfera de influencia virreinal inmediata. ${ }^{50}$ También parece ser que sólo unas pocas personas pertenecientes a círculos novohispanos establecidos o comerciantes ligados al consulado tuvieron que partir para España. ${ }^{51}$

Ciertamente existen diversos problemas metodológicos en la reconstrucción de la red social de Revillagigedo. Michel Bertrand señaló que la simple existencia de contactos entre personas no necesariamente indica solidaridad, 52 esto es especialmente cierto para un virrey que se comunicaba con muchos habitantes del reino. Sin embargo, algunos de los vínculos virreinales eran profundos y duraderos, como indicaron repetidas recomendaciones que hizo Revillagigedo. Él y Cevallos, por ejemplo, mantuvieron correspondencia a lo largo de décadas y conservaron su amistad, relación que fue confirmada incluso por el consulado, que era hostil hacia Cevallos. Asimismo, hay que tomar en cuenta que la evidencia de los enlaces difiere para cada cliente, y, por ejemplo, muestra una débil relación con Ignacio Negreiros y Herrera, quien también fue deportado. Negreiros y Herrera testificó en los juicios

49 Ver fuentes en el apéndice.

50 Un ejémplo es David Brading, Mito y profecía en la historia de México, México: Fondo de Cultura Económica, 2004, pp. 80-88, aunque los estudiosos se han distanciado últimamente de estudiar a los criollos.

51 Excepto por Pedro Núñez de Villavicencio, vástago de una notable familia criolla con múltiples contactos con la aristocracia; consúltese las indicaciones de sus vínculos con el conde de Santiago de Calimaya en Javier Sanchiz / José Ignacio Conde Díaz-Rubín, Historia genealógica de los títulos y dignidades nobiliarias en Nueva España y México. Vol. 1. La Casa de Austria, México: UNAM, 2008, p. 207.

52 Michel Bertrand, "Del actor a la red. Análisis de redes e interdisciplinariedad": Evelyne Sanchez (ed.), Los actores locales de la nación en la América Latina. Análisis estratégicos, Puebla / Tlaxcala: Benemérita Universidad Autónoma de Puebla / El Colegio de Tlaxcala, 2011, p. 32. 
de residencia de dos ministros de la audiencia, que habían colaborado estrechamente con Revillagigedo. No obstante, Negreiros y Herrera no llegó a México sino hasta 1761 y, aunque no se puede excluir la posibilidad, no hay evidencia de que fuera un cliente virreinal cercano. ${ }^{53}$

Del mismo modo, la relación entre Revillagigedo y Francisco Javier de Gamboa, el famoso abogado novohispano, inicialmente fue distante, pero hay indicios de que con el tiempo se estrechó. Gamboa había nacido en una familia de escasa riqueza, y estudió en los colegios de la Compañía de Jesús, gracias a la protección de uno de los ministros de la audiencia de Guadalajara. Revillagigedo contrató a Gamboa para escribir al menos un informe jurídico, y permitió que en 1755 viajara a España para representar al consulado por la controversia de la alcabala, en tanto que había negado dicha oportunidad a los regidores del cabildo civil. Gamboa publicó sus comentarios eruditos sobre la minería en 1761, donde criticó a Revillagigedo por haber intervenido en la alcaldía mayor de Bolaños en Nueva Galicia. ${ }^{54}$ Atacar a un partidario de la camarilla de Ensenada probablemente era visto con buenos ojos por el Consejo de Indias durante el gobierno de Ricardo Wall. No obstante, Gamboa permaneció en Madrid, donde debe de haberse comunicado con Revillagigedo de alguna forma después de su llegada. El antiguo virrey advirtió en 1763 que el abogado trató de regresar a la Nueva España y se lamentó de que "el pobre Gamboa ha estado esperanzado de ir ahí con la toga, le ha salido este S[an]to B[uen]o con la fresca".55 Finalmente, en 1765, Gamboa obtuvo la codiciada posición de alcalde del crimen de México. 56

53 Ver fuentes en el apéndice.

54 Christopher Peter Albi, "Derecho Indiano vs. the Bourbon Reforms. The Legal Philosophy of Francisco Xavier Gamboa": Gabriel Paquette (ed.), Enlightened Reform in Southern Europe and its Atlantic Colonies. C. 1750-1830, Ashgate: Farnham, 2009, pp. 229-249, ve a Gamboa como un defensor de la tradicional casuística y del derecho romano. Con todo, el enfoque legal de Gamboa fue influido por sus vínculos con el consulado. Sobre la educación jesuita de Gamboa, véase Francisco Iván Escamilla González, "La iglesia y los orígenes de la ilustración novohispana": María del Pilar Martínez López-Cano (ed.), La iglesia en Nueva España. Problemas y perspectivas de investigación, México: UNAM, 2010, p. 115. 55 Revillagigedo a Cevallos, Madrid, 9 de octubre de 1763, ACR, 396.

56 Consulado a Revillagigedo, México, 9 de abril de 1755; el fiscal de lo civil Antonio Andreu y Ferraz a Revillagigedo, México, 10 de abril de 1755, ambos documentos en AGN, Civil 1332, exp. 1, fols. 1-2; relación de méritos de Gamboa, Madrid, 1 de 


\section{El partido "antigubernativo" y Revillagigedo}

Varios de los sospechosos habían asistido a escuelas jesuitas, recibieron apoyo de la orden, o se pronunciaron a su favor. Algunos testigos, por ejemplo, escucharon que el prebendado Ignacio Javier de Esnaurrizar clamaba que el rey "estaba condenado y excomulgado" por la expulsión de los jesuitas. Esnaurrizar se negó a retractarse, y fue encarcelado y enviado a España para ser enjuiciado. ${ }^{57}$ Mientras tanto, Ignacio Cevallos y Francisco Javier de Gamboa habían estudiado en escuelas de jesuitas. Es cierto que muchos novohispanos se formaron en esas escuelas y no resistieron de manera directa a la expulsión, pero se puede asumir que los estudios crearon entre muchos lazos de solidaridad con los ignacianos. Además, en 1751 el alcalde del crimen, Diego Fernández de Madrid, obtuvo su posición en la audiencia con la ayuda del exconfesor real, el jesuita Francisco Rávago y Noriega. En ese entonces, el provincial jesuita de la Nueva España fomentó la designación porque consideraba que el padre de Fernández de Madrid era un gran benefactor de la orden. ${ }^{58}$ Revillagigedo estuvo de acuerdo. ${ }^{59}$

El gobierno madrileño carecía de pruebas suficientes para condenar a la mayoría de los deportados - quienes declararon profusamente su lealtad-y promovió a varios de ellos a posiciones comparables e igual de codiciadas en la península. Gamboa, por ejemplo, se convirtió en fiscal del crimen en la chancillería de Barcelona y regresó a la Nueva España en 1773, donde sería regente de la audiencia y falleció en 1794. ${ }^{60}$ Cevallos llegó a ser canónigo del cabildo catedralicio en Sevilla,

febrero de 1757, AGI, Indiferente 157, N. 6, 1, 1-6, fols. 1-3v; Revillagigedo al rey, México, 6 de octubre de 1753, AGI, México 1349; véase también Mariano Otero, "Apuntes para la biografía de Don Francisco Javier Gamboa": Revista de la Facultad de Derecho de México, 105: 1 (1977), pp. 358, 364.

57 Citado en Zahíno Peñafort, "El criollo mexicano", p. 120, nota 28.

58 Escamilla González, "Los confesores reales", pp. 241-242.

59 Ver en la tabla 2 la entrada de Diego Fernández de Madrid.

60 Sobre Gamboa, ver Bucareli a Arriaga, México, 26 de noviembre de 1772, AGN, Correspondencia de Virreyes 5, exp. 1, fols. 405-406; Branciforte a Llaguno, México, 29 de agosto de 1794, AGN, Correspondencia de Virreyes 179, fol. 32-32v; Mariano Otero, "Apuntes", p. 365; Navarro García, "Destrucción", pp. 19-25; Burkholder / Dewitt Samuel Chandler, Biographical Dictionary of Audiencia Ministers in the Americas, 1687-1821, Westport, Colorado: Greenwood, 1982, pp. 346-347. 
en el cual ascendió a deán antes de fallecer en 1784. El fiscal Velarde y Cienfuegos se unió a la chancillería de Granada y más tarde fue promovido al Consejo de Castilla, no por casualidad un par de días antes de la muerte de José de Gálvez. Antonio Lorenzo López Portillo obtuvo una prebenda en Valencia, mientras que Martín de Azpiroz fue asignado a la secretaría del Consejo de Real Hacienda en Madrid. José Rafael Rodríguez Gallardo regresó a la Nueva España en 1774 como contador mayor del Tribunal de Cuentas de México.61

Si bien José de Gálvez y Revillagigedo compartían un origen más bien humilde, pertenecían a dos diferentes grupos de interés en la corte española. Tal conformación pudo haber exacerbado el conflicto entre los clientes de ambos, aunque esto sigue siendo un tanto especulativo. Desde mediados del siglo XVIII varios grupos competían por el poder en Madrid. Éstos incluían a militares de carrera que a menudo se graduaban de academias militares y poseían habilidades técnicas y de gestión. Además, muchos de los nobles y algunos aristócratas tenían grados en derecho de las prestigiosas universidades de Salamanca, Valladolid y Alcalá de Henares, donde se asociaron con los colegios mayores, en los cuales los jesuitas ejercían su amplia influencia. Se distinguían de los abogados que se graduaron de las universidades menores y que eran adeptos al pensamiento ilustrado $y$ al fortalecimiento de la monarquía. ${ }^{62}$ Revillagigedo mismo era oficial de carrera, aunque no había estudiado en una academia militar. Gálvez, por su parte, sí asistió a las universidades de Salamanca y Alcalá de Henares, aunque no a un colegio mayor, y procedía de la nobleza andaluza venida a menos. En tanto, Croix era oficial de carrera como Revillagigedo, pero descendía de un linaje prestigioso. 63

61 Adolfo de Salazar Mir, Los expedientes de limpieza de sangre de la Catedral de Sevilla (Genealogías), t. 2, expedientes 542 al 915, Madrid: Hidalguía, 1996, pp. 94-95; Diccionario biográfico español, "Ignacio de Ceballos Villagutierre": DBE, RAH, en línea: http://dbe.rah.es/ [12-10-2020]; Zahíno Peñafort, "El criollo mexicano", p. 120, nota 28. Según Arriaga al marqués de Real Tesoro, San Ildefonso, 13 de agosto de 1773, AGI, Contratación 5518, N. 1, R. 63, fol. 1, Ignacio Negreiros y Herrera regresó a México en 1773, para reanudar su trabajo como contador del Tribunal de Cuentas.

62 Pietschmann, "Antecedentes politicos", p. 45.

63 Serrano Álvarez, "Croix, Carlos Francisco de"; Feliciano Barrios Pintado, "Gálvez y Gallardo, José de"; Pilar Latasa Vassallo, "Güemes y Horcasitas, Juan Francisco de", las tres entradas en DBE, RAH, en línea: http://dbe.rah.es/ [12-10-2020]. 
Así mismo, Revillagigedo pertenecía a la red social de Ensenada que originalmente había sido dirigida por José Patiño, ministro clave de 1726 hasta 1736. Patiño, su hechura Ensenada, y Revillagigedo eran parte de una nobleza de servicio que se formó en las campañas militares en Italia y África. Patiño participó en la ocupación de Cerdeña y Sicilia en 1717-1718, mientras que Revillagigedo y Ensenada se conocieron durante la conquista de Orán (Argelia) en 1732. Igualmente, Revillagigedo y Ensenada eran ambos del norte de España. En tanto que José de Gálvez fue cortado de otra tela, ya que había nacido cerca de Málaga en Andalucía y gozaba de la protección del cardenal Gaspar de Molina y Oviedo, obispo de Málaga desde 1734. Gálvez se casó bien y sirvió como alcalde de corte y casa bajo la supervisión del Consejo de Castilla antes de desempeñarse como visitador general. ${ }^{64} \mathrm{Al} \mathrm{mismo}$ tiempo, Ensenada y Gálvez estaban en deuda con el mismo rey; Gálvez por sus varios nombramientos mientras Ensenada consiguió el título de nobleza de Carlos en 1736 al coordinar la exitosa campaña para instalarlo como rey de Nápoles. ${ }^{65}$ Ahora bien, las diferentes biografías de los dos ministros y sus posibles pertenencias a grupos de interés en conflicto no significaban necesariamente que los actores no pudieran formar alianzas. Las redes sociales bien podían atravesar esos grupos y realinearse en torno a intereses comunes. De todas maneras, los grupos de interés en la corte tuvieron relevancia en producir decisiones políticas.

\section{Conclusión}

Cuando Revillagigedo le quitó la alcabala al consulado, colaboró con algunos comerciantes que estaban conectados con su asesor más importante, el canónigo Ignacio Cevallos. Este grupo ofreció al virrey apoyo local, mientras que hay evidencia de que Cevallos y

64 Francisco A. Eissa Barroso, "La Nueva Granada en el sistema de Utrecht. Condiciones locales, contexto internacional, y reforma institucional”: Iván Escamilla González / Matilde Souto Mantecón / Guadalupe Pinzón Ríos (eds.), Resonancias imperiales. América y el tratado de Utrecht de 1713, México: UNAM, Instituto Mora, pp. 69-71; Kuethe / Andrien, Atlantic World, p. 143, 249; Barrios Pintado, "Gálvez."

65 José Luis Gómez Urdáñez, El proyecto reformista de Ensenada, Lleida: Milenio, 1996, p. 66; Stein / Stein, Silver, Trade, and War, p. 236. 
probablemente otros se beneficiaron del patronazgo virreinal. Revillagigedo tuvo éxito con su proyecto, lo que impulsó sustancialmente su carrera. El virrey también nombró a otros novohispanos para ocupar importantes posiciones en el gobierno, y tres de ellos estaban vinculados con Cevallos. Luego la política cambió. Ensenada cayó en 1754 y un gobierno más conservador hizo volver a Revillagigedo a España, aunque Cevallos y algunos otros clientes continuaron comunicándose con él.

En 1763, el rey Carlos III nombró a Esquilache como secretario de la Real Hacienda y ordenó una visita general de la Nueva España en 1765. Revillagigedo se benefició del nuevo gobierno, pero falleció en 1766, con lo que sus antiguos clientes perdieron un poderoso aliado en Madrid. En 1767 Gálvez y Croix expulsaron a los jesuitas y Croix acusó a dieciséis habitantes de oponerse a la expulsión, ocho de los cuales habían sido clientes de Revillagigedo, entre ellos Cevallos. Croix fue sumamente riguroso con la clientela de su antecesor, y mandó a seis de ellos a España. Sin embargo, la acusación adquiere nuevos matices ante la evidencia de que este grupo fue en origen pro-gubernativo al colaborar con el virrey reformista Revillagigedo. De igual forma, los vínculos virreinales con personas pro-jesuitas se asemejan hasta cierto punto a la alianza que Ensenada forjó en España. De esta perspectiva, también resulta claro que la oposición a la visita de Gálvez consistía de criollos, mineros o indios, como los historiadores han mostrado, y también de una red de partidarios virreinales con diversas procedencias regionales en América y España.

Existe hoy un amplio consenso en que Ensenada y Gálvez impulsaron reformas significativas, pero Gálvez causó una agitación en contra de sus medidas. Revillagigedo seguía las órdenes de Ensenada y efectuó pacíficamente la transferencia de la alcabala, después de secularizar más de cien doctrinas regulares. Mientras tanto, Gálvez impuso recaudaciones tributarias más rigurosas, estableció milicias, y tomó otras medidas impopulares. La expulsión de los jesuitas como consecuencia provocó una conmoción entre la región de Michoacán y San Luis Potosí y la resistencia de funcionarios en México en 1767, varios de los cuales habían tenido buenas relaciones con la corte en Madrid hasta el año anterior. 


\section{Apéndice \\ El partido "antigubernativo" y Revillagigedo ${ }^{66}$}

1. Nombre por orden alfabético

2. Origen

3. Posición

4. Relación con Revillagigedo o Ignacio Cevallos

5. Castigo

66 Fuentes: Revillagigedo a Ensenada, México, 23 de enero de 1752, AGI, México 1506, no. 109; Revillagigedo del rey, México, 6 de febrero de 1753, ACR, 412; Brading, Miners, p. 39; Navarro García, “Destrucción,” pp. 19-25; Martín de Aspiroz: Castro Santa-Anna, Diario, 5: 147; del Valle Menéndez, Güemes, p. 561; Ignacio Cevallos: ver notas a pie de página 19-21; Martín Crespo: Según la certificación de Ignacio Cevallos, Cádiz, 20 de diciembre de 1747, AGI, Contratación 5489, N. 2, R. 12, fol. 8, Crespo viajó con Cevallos a la Nueva España. Este es probablemente el mismo padre Crespo que, según Navarro García, "Destrucción", pp. 11, 14, fue enviado a España; Diego Fernández de Madrid: testimonio de Fernández de Madrid, AGI Escribanía, 246 B, fols. 284v-290; Revillagigedo a Ensenada, México, 14 de septiembre de 1748, ACR, 395; Revillagigedo al rey, México, 3 de noviembre de 1750, AGI, México 544; consulta de la Cámara de las Indias, Madrid, 17 de julio de 1751, y el título de nombramiento como alcalde de crimen supernumerario, Aranjuez, 14 de mayo de 1751, ambos documentos en AGI, México 443; Sobre Antonio López Portillo: Dorothy Tanck de Estrada, "El rector desterrado. El surgimiento y la caída de Antonio López Portillo, 1730-1780": Enrique González y González / Leticia Pérez Puente (ed.), Permanencia y cambio. Universidades hispánicas, 1551-2001, México: UNAM, 2006, pp. 181-188; Brading, Miners, p. 39; Francisco López Portillo: título de Fernando VI, Buen Retiro, 8 octubre de 1747, AGI, Guadalajara 81; Mark A. Burkholder, "Francisco de López Portillo": Real Academia de la Historia, Diccionario Biográfico electrónico [DBE, RAH], en línea: http://dbe.rah.es/ [12-10-2020]; Pedro Núñez de Villavicencio: Revillagigedo a Núñez de Villavicencio, México, 8 de marzo de 1761, ACR 404, y Revillagigedo a Villavicencio, Madrid, 1 de julio de 1763, ACR, 387; relación de méritos, AGI, Indiferente 148, N. 58; testimonio de Juan Crisóstomo de Barroeta, 17 de enero de 1757, AGI, Escribanía 246B, fol. 27v; José Rafael Rodríguez Gallardo: el testimonio de Nicolás Peinado en el juicio de residencia de Revillagigedo, México, 21 de enero de 1757, AGI, Escribanía, 246 B, fols. 100-100v; testimonio de Rodríguez Gallardo, México, 9 de febrero de 1757, ibíd., fols. 341-343; relación de méritos de Rodríguez Gallardo, AGI, Indiferente 157, N. 32, 1, fols 1-3; relación de méritos de Rodríguez Gallardo, AGI, Indiferente 157, N. 16, 7, fols. 1-2r. Según Navarro,

Jahrbuch für Geschichte Lateinamerikas | Anuario de Historia de América Latina 
1. Martín de Aspiroz

2. Desconocido

3. Contador supernumerario del tribunal de cuentas, oficial primero de la secretaría del virreinato

4. Dos nombramientos virreinales

5. Llamado a España

1. Ignacio Felipe Cevallos Villagutierre

2. Guatemala, padres eran originarios de Salamamca (León), educación jesuita

3. Canónigo

4. Asesor de Revillagigedo, amplia correspondencia con Revillagigedo

5. Llamado a España

"Destrucción," pp. 13, 17, él era conocido por ser un cliente del oidor Domingo Valcárcel; sobre Esnaurrizar, Mella y Ulloa, Serruto y Nava, y Vives, ver Luisa Zahíno Peñafort, "El criollo mexicano Francisco Vives y su correspondencia desde la Francia revolucionaria: de canónigo catedralicio a miembro de una sociedad jacobina": Estudios de Historia Novohispana, 15 (1995), pp. 114, 120, esp. nota 28; Francisco Javier de Gamboa: Revillagigedo a Ignacio Cevallos, Madrid, 9 de octubre de 1763, ACR, 396; Revillagigedo al rey, México, 6 de octubre de 1753, AGI, México 1349; relación de méritos, Madrid, 1 de febrero de 1757, Indiferente 157, N. 6, 1, de 1 a 6, fols. 1-3v, relación de méritos, Madrid, 22 de diciembre de 1759, AGI, Indiferente 159, N. 35; Ignacio Negreiros y Herrera: de acuerdo a José Ignacio de Goyeneche, Casa de Contratación, Madrid, 1 de marzo de 1761, AGI, Contratación 5505, N. 1, R. 49, fol. 1-1v, Negreiros y Herrera llegó en 1761 a la Nueva España y apoyó a Luis de Mosquera y Pimentel, marqués de Aranda en el juicio de residencia, véase el testimonio de Negreiros, México, 13 de septiembre de 1764, AHN, Consejos 21460, exp. 7, cuaderno 2, fol. 35; testimonio de Negreiros en la residencia de Domingo de Trespalacios y Escandón, sin fecha, México, AHN, Consejos 21461, exp. 2, fol. 3. Sobre las recomendaciones virreinales para Aranda y Trespalacios y Escandón, véase, por ejemplo, Revillagigedo al rey, México, 30 de junio de 1753, AGI, México 516; Revillagigedo al rey, México, 18 de diciembre de 1752, AGI, México 516; véase también Revillagigedo al rey, México, 30 de junio de 1749, ACR, 379; juicio de residencia de Revillagigedo, AGI, Escribanía 246 B, fol. 304; Pedro de Rada: Javier Barrientos Grandon, "Pedro de Rada y Aguirre": DBE, $\mathrm{RAH}$, en línea: http://dbe.rah.es/ [12-10-2020]; Juan Antonio Velarde y Cienfuegos: Burkholder, "Juan Antonio Velarde y Cienfuegos": DBE, RAH, en línea: http://dbe.rah.es/ [12-10-2020].

Jahrbuch für Geschichte Lateinamerikas | Anuario de Historia de América Latina 


\section{Martín Crespo}

2. México / Guatemala (?)

3. Desconocido

4. Capellán de Cevallos

5. Encarcelado y deportado

1. Diego Fernández de Madrid

2. Guatemala

3. Oidor

4. Testigo favorable en el juicio de residencia virreinal, Revillagigedo aprobó su nombramiento, Francisco Rávago y Noriega ayudó a conseguirlo

5. Retiro al convento

1.Antonio Lorenzo López Portillo

2. Guadalajara, educado en colegios jesuitas de San Juan, Guadalajara y San Ildefonso de la Universidad de México

3. Prebendado en el capítulo catedralico de México

4. Primo de Cevallos, primo adoptivo de Francisco López Portillo

5. Llamado a España

1.Francisco López Portillo

2. Guadalajara, educado en el colegio jesuita de San Ildefonso de la Universidad de México

3. Desde 1747 oidor supernumerarui de la audiencia de Guadalajara; desde 1764, oidor de la audiencia de México

4. Primo de Antonio Lorenzo López Portillo

5. Encarcelado en El Morro, la Habana; deportado

1. Pedro Núñez de Villavicencio

2. México

3. Superintendente de la Casa de Moneda de México

4. Nombramiento virreinal, recomendación al Consejo de las Indias

5. Acusado 
1. José Rafael Rodríguez Gallardo

2. Yucatán

3. Contador general de reales tributos

4. Nombramientos virreinales como contador general interino y visitador y gobernador interino de Sinaloa y Sonora

5. Llamado a España

Sin relación directa con Revillagigedo:

1. Francisco Javier de Gamboa

2. Guadalajara

3. Alcalde del crimen de la audiencia de México, apoderado del consulado

4. Una asesoría legal para Revillagigedo, después contactos en Madrid

5. Llamado a España

1. Ignacio Javier de Esnaurrízar

2. Desconocido

3. Prebendado en el capítulo catedralicio de México

4. Desconocido

5. Encarcelado en San Juan de Ulúa y El Morro, deportado

1. Alonso de Mella y Ulloa

2. Desconocido

3. Contador mayor decando del Real Tribunal de Cuentas

4. Desconocido

5. Acusado

1. Ignacio Negreiros y Herrera

2. Sevilla, Andalucía

3. Contador de la mesa mayor del Real Tribunal de Cuentas

4. Testigo a favor de amigos virreinales

5. Llamado a España 
1. Pedro de Rada

2. Castro Urdiales, Cantabria

3. Secretario del virreinato del marqués de Croix

4. Desconocido

5. Llamado a España

1. José Serruto y Nava

2. Educado en las escuelas jesuitas Colegio Máximo y el Colegio de San Ildefonso

3. Prebendado del capítulo catedralicio de México

4. Desconocido

5. Acusado

1. Juan Antonio Velarde y Cienfuegos

2. Asturias, sirvió antes en Santo Domingo y Guatemala

3. Fiscal de lo civil de la audiencia de México

4. Desconocido

5. Llamado a España

1. Francisco Vives

2. Veracruz, educado en los colegios jesuitas de San Ignacio y de San Ildefonso

3. Medio racionero del capítulo catedralicio de México

4. Desconocido

5. Absuelto 